\title{
FILOZOFIA JAKO ĆWICZENIE DUCHOWE. COACHINGOWY MODEL UPRAWIANIA FILOZOFII
}

\begin{abstract}
Streszczenie. Główną tezą tekstu jest uznanie tzw. modelu coachingowego za pierwotny i wciąż żywy sposób uprawiania filozofii. Twierdzę, że filozofia akademicka, która od kilku stuleci tkwi w tradycji scholastycznej, może być uprawiana w modelu coachingowym. W drugim paragrafie przedstawiam odróżnienie dwóch rodzajów filozofowania: Sokratejskiego - określonego w tekście mianem „coachingowego” - oraz Arystotelesowskiego, nazywanego tutaj „scholastycznym”. W trzecim paragrafie pokazuję, w jaki sposób Wiktor Frankl nawiązuje do coachingowej tradycji uprawiania filozofii w swojej praktyce terapeutycznej. W czwartym przedstawiam przykłady zastosowania modelu coachingowego w dydaktyce filozofii.
\end{abstract}

Słowa kluczowe: model coachingowy filozofii, model scholastyczny, logoterapia, sumienie, ćwiczenie duchowe, ćwiczenia coachingowe, serce, medytacja

1. Wstęp. 2. Dwa sposoby rozumienia filozofii: coachingowy i scholastyczny. 3. Coaching filozoficzny jako logoterapia. 4. Coaching filozoficzny jako metoda dydaktyczna. 5. Przykłady ćwiczeń coachingowych w dydaktyce filozoficznej.

\section{WSTĘP}

Tekst ten jest częścią zbioru artykułów, którego celem jest opracowanie podstaw teoretycznych coachingu filozoficznego - nowej dyscypliny praktycznej, która od roku 2016 stanowi składnik oferty edukacyjnej Uniwersytetu Opolskiego. Od kilku lat niektóre Instytuty Filozofii w Polsce włączają coaching i doradztwo filozoficzne do swojej oferty edukacyjnej. Jednak filozofia akademicka rozumiana jako sztuka pisania rozpraw naukowych nie gwarantuje studentom uzyskania praktycznych kompetencji potrzebnych doradcy czy coachowi. Sama znajomość doktryn filozoficznych, nawet jeśli mają one swój wymiar praktyczny, a nawet sama umiejętność bronienia 
swojego stanowiska w dyskusji, nie wystarczy. Jeśli absolwent coachingu filozoficznego ma być gotowy do wykonywania swojego zawodu, powinien w toku studiów odbywać ćwiczenia podobne do tych, które przechodzą praktycy - trenerzy, coache czy terapeuci. Najbardziej jednak naturalnym sposobem „upraktycznienia” studiów filozoficznych jest podjęcie wysiłku odnalezienia i wykorzystania w praktyce akademickiej ćwiczeń wykonywanych przez adeptów filozofii w czasach, gdy nie miała ona jeszcze charakteru scholastycznego, lecz, jak proponuję to określać, „coachingowy”.

Mimo iż filozofia akademicka od kilku stuleci podąża konsekwentnie drogą tradycji scholastycznej, możliwe jest dzisiaj wracanie do coachingowo uprawianej filozofii w ramach praktyki uniwersyteckiej. W pierwszej części tekstu przedstawiam odróżnienie dwóch rodzajów filozofowania: Sokratejskiego - określonego w tekście mianem coachingowego - oraz Arystotelesowskiego - nazywanego tutaj scholastycznym. Odnoszę się też do faktu stopniowego zanikania wymiaru coachingowego w filozofii. W drugiej części pokazuję, w jaki sposób w XX wieku terapeuci, tacy jak Wiktor Frankl i Albert Ellis, sięgnęli do coachingowej tradycji uprawiania filozofii w swojej praktyce terapeutycznej. W trzeciej przedstawiam przykłady zastosowania tego modelu w dydaktyce filozofii.

\section{DWA SPOSOBY ROZUMIENIA FILOZOFII: COACHINGOWY I SCHOLASTYCZNY}

W epoce starożytnej zarysowują się dwie tradycje uprawiania filozofii, które można określić jako tradycję scholastyczno-teoretyczną

1 Nie ma niestety dobrego polskiego odpowiednika wyrażenia „coaching”. Nazwa ta pochodzi od angielskiego wyrazu coach - trener. Osobą, która zainicjowała rozwój coachingu w dzisiejszym rozumieniu tego słowa był trener tenisa, Tim Gallwey. Istotą jego trenerskiej działalności nie było podnoszenie wąsko rozumianej efektywności sportowca liczonej na przykład w punktach rankingowych, lecz coś, co można nazwać rozwojem duchowym. Gallwey zwracał uwagę na świadomość ciała, pracę z uwagą oraz przemianę 
i tradycję coachingową. Arystoteles jako domniemany autor wykładów stanowiących zapis usystematyzowanej wiedzy naukowej IV wieku p.n.e. jest prototypem dzisiejszego profesora uniwersyteckiego, pracownika naukowego, który tworzy system wiedzy „nadającej się do nauczania”2 (czytaj: „wykładania”). Wiedza jest tu traktowana jako twór istniejący względnie samodzielnie, w postaci obiektywnych treści, najlepiej zapisanych i uporządkowanych tematycznie. Wiedza tak rozumiana jest uznawana za wiedzę obiektywną w tym znaczeniu, że może być przekazywana niezależnie od kontekstu osobistego doświadczenia wykładowcy i słuchacza. Osobiste, czy osoborve, spotkanie mistrza i ucznia nie jest integralną częścią scholastycznej praktyki filozoficznej. Filozof-teoretyk to osoba zajmująca się „tworzeniem nauki”, tj. pisaniem tekstów, wygłaszaniem wykładów i obroną głoszonych tez. Swą tożsamość buduje poprzez konfrontowanie się $\mathrm{z}$ twierdzeniami oponentów, poprzez szukanie najlepszych rozwiązań problemów teoretycznych, a przede wszystkim pisanie dzieł powiększających zasoby wiedzy obiektywnej. Filozof scholastyczny jest znawcą, ekspertem w określonej dziedzinie wiedzy, którego wiarygodność potwierdzają inni znawcy. Tradycja ta zawiera w formie zaczątkowej podstawowe cechy współczesnej nauki i już

myślenia w kierunku odkrywania i rozwijania wewnętrznego wymiaru zmagań sportowych. Por. T. Gallwey, Tenis. Wewnętrzna gra, tłum. z ang. R. Madejczyk, Łódź 2015. Nazwa „coaching” jako określenie nauczycielskiej działalności Sokratesa, Epikura czy Epikteta jest z pewnością za wąska, kiedy, z jednej strony, przyjmujemy „podręcznikowe” rozumienie filozofii starożytnej, a z drugiej strony, odmawiamy coachingowi jego wymiaru duchowego. Jeśli jednak przyjmujemy perspektywę spojrzenia na filozofię starożytną, jaką proponuje Pierre Hadot, a coaching rozumiemy szeroko jako rodzaj treningu mentalnego i pracę nad rozwojem człowieka we wszystkich jego wymiarach, określenie 'filozoficzny coaching' w odniesieniu do działalności Sokratesa i jego kontynuatorów wydaje się trafne.

2 „Wszelka wiedza naukowa jest - jak się zdaje, czymś czego można nauczyć, a jej treść czymś, czego można nauczyć się". Arystoteles, Etyka Nikomachejska, tłum. z gr. D. Gromska, Kraków 1956, 210. 
w starożytności doprowadziła do takich zjawisk, jak na przykład „rewolucja naukowa” w Aleksandrii ${ }^{3}$.

Sokrates nie definiuje siebie w kontekście żadnej z doktryn czy twierdzeń filozoficznych, jakie zdarza mu się wygłaszać. Jego sposób uprawiania filozofii jest przykładem filozoficznego coachingu, który radykalnie różni się od scholastycznej tradycji uprawiania filozofii ${ }^{4}$. Sokratesowi nie chodzi o gromadzenie i przekazywanie wiedzy w postaci zobiektywizowanych twierdzeń, lecz o uaktywnianie wewnętrznych zasobów konkretnego rozmówcy, o jego wewnętrzną przemianę. Sokratejskie filozofowanie spełnia się w wymiarze dydaktycznym, lecz nie jako wykład, a jako dostosowane do konkretnego rozmówcy ćwiczenie duchowe ${ }^{5}$, według reguł metody elenktyczno-majeutycznej.

Warto zwrócić uwagę na fakt, że Sokratejski model uprawiania filozofii, kontynuowany i rozwijany przez jego uczniów nie jest czymś, co przydarza się Sokratesowi ze względu na jego cechy osobiste, lecz że jest to licznie reprezentowana i wpływowa w epoce starożytnej tradycja, która w V wieku przed naszą erą posiada już swoje dobrze określone cele i metody. Sokratesa znamy przecież głównie dzięki opisom twórcy Akademii, gdzie uprawiano filozofię rozumianą jako ćwiczenia duchowe, wywodzące się z ezoterycznych bractw Pitagorejskich ${ }^{6}$. Filozofia uprawiana w tym modelu opiera się na realnych związkach przyjaźni między osobami, które gotowe

3 Por. np. L. Russo, Zapomniana rewolucja: grecka myśl naukowa a nauka nowoczesna, tłum. z wł. I. Kania, Kraków 2005.

4 Słynna Sokratejska krytyka pisma jest jednocześnie krytyką scholastycznego modelu uprawiania filozofii. Platon, Fajdros, tłum. z gr. W. Witwicki, Kęty 2002, 50.

5 Terminu „duchowy” używam w sensie proponowanym przez Wiktora Frankla: „(...) chciałbym uniknąć skojarzeń religijnych, chodzi mi wyłącznie o podkreślenie faktu, że mamy do czynienia ze zjawiskiem właściwym wyłącznie człowiekowi”. V. Frankl, Bóg ukryty. W poszukiwaniu ostatecznego sensu, tłum z ang. A. Wolnicka, Warszawa 2016, 41.

6 Por. P. Hadot, Filozofia jako ćwiczenie duchowe, tłum. z fr. P. Domański, Warszawa 2003; S. Weil, Szaleństwo miłości. Intuicje przedchrześcijańskie, tłum. z fr. M. Plecińska, Poznań 1994. 
były podporządkować swój egoistycznie rozumiany interes poszukiwaniu Mądrości. Istotniejsze niż zobiektywizowane twierdzenia są tu techniki i narzędzia „wspomagania” osób zdecydowanych podążać ścieżką rozwoju duchowego. Ten model uprawiania filozofii wyklucza wszelki dogmatyzm i doktrynerstwo, ale też profesjonalną interesowność. Zakłada on absolutny prymat wartości moralnych nad utylitarnymi i jest sposobem życia, który dziś kojarzy się nam z porzuceniem kariery osobistej na rzecz powołania monastycznego. Jednym z głównych a zarazem najbardziej dramatycznych motywów Platońskich dialogów jest konfrontacja tego modelu uprawiania filozofii ze "scholastycznym” profesjonalizmem sofistów. Słowo 'scholastyczny' w odniesieniu do sofistów w tym kontekście może być mylące, gdyż to Platoński Sokrates (którego nie należy utożsamiać z Sokratesem historycznym) prezentuje metody wypracowane w ramach szkoły - Akademii, a sofiści z kolei przypominają wielu współczesnych coachów - mistrzów mów motywacyjnych, którzy za dobrą cenę sprzedają swoje "narzędzia coachingowe” obywatelom spragnionym sukcesu politycznego. Istotą filozofii uprawianej $\mathrm{w}$ modelu coachingowym, w proponowanym tu rozumieniu, nie jest jednak stosowanie „narzędzi motywacyjnych”, lecz praktyka duchowa, której celem jest uwolnienie się od wewnętrznych niepokojów, wzmocnienie siły psychicznej, pozbycie się autodestrukcyjnych nawyków myślowych, postęp moralny, słowem nie sukces polityczny, ale „wyzwolenie duszy”.

Akademia Platońska nie jest szkołą w dzisiejszym znaczeniu tego słowa. Posiada, na wzór Pitagorejski, swoją naukę niepisaną oraz techniki i ćwiczenia służące „wyzwalaniu duszy z więzów ciała”. $\mathrm{Na}$ podstawie dialogów oraz innych zachowanych tekstów można próbować rekonstruować, jak to czyni Pierre Hadot, niektóre techniki stosowane w Akademii Platońskiej. Jednak droga do tej rekonstrukcji wiedzie nie tylko przez analizy zachowanych źródeł pisanych. Interesującym dopełnieniem analiz historycznych może być próba 
podążania za intuicjami Platońskimi we współczesnej praktyce nauczania filozofii oraz w coachingu?

Dialog Sokratejski jest też jedną z technik współczesnej logoterapii. W logoterapii i coachingu filozoficznym, jak staram się to niżej uzasadnić, cele i metody są podobne. W obu mamy do czynienia $\mathrm{z}$ pracą $\mathrm{w}$ obszarze wyższych funkcji psychicznych człowieka, które można określić jako duchowe, takich, jak samoświadomość, etyczna wrażliwość czy wola sensu. W jednym i drugim mamy do czynienia $\mathrm{z}$ „elenktycznym” wykrywaniem niespójności w myśleniu i zmianą destrukcyjnie wpływających na jednostkę przekonań, a także „majeutyczne” skierowanie uwagi na przestrzeń osobistego doświadczenia Dobra ${ }^{8}$. W obu zakłada się, że przemiana myślenia (metanoia) prowadzi do lepszego życia.

„Polepszanie życia” (oczywiście nie chodzi tu o utylitarny sens tego wyrażenia) konkretnej filozofującej jednostki, a nie powiększanie zasobów abstrakcyjnej wiedzy „nadającej się do nauczania” jest celem filozofii, którą uprawiają uczniowie Sokratesa - Antystenes i Arystyp, a po nich Diogenes z Synopy, Zenon z Kition, Epikur, Pirron,

7 Według Simone Weil „w dzisiejszych czasach głębia myśli pitagorejskiej jest dla nas dostępna jedynie przez intuicję, możemy tam dotrzeć od wewnątrz". S. Weil, dz. cyt., 91. Przykładem prób rekonstruowania Sokratejskiej majeutyki, we współczesnym coachingu filozoficznym jest opracowana przez Tomasza Femiaka i opisana w tym tomie „sztuka uświadomionego mówienia”. Zakłada ona konieczność odejścia od współczesnej naturalistycznej wizji ludzkiej psychiki i zastosowanie w coachingu filozoficznym założeń homeryckiej psychologii. Innym przykładem odrzucenia naturalizmu i odwołania się do założeń antycznej psychologii mogą być opisane przez franciszkanina Richarda Rohra techniki pracy z enneagramem, które opierają się na platońskiej koncepcji trzech ośrodków życia psychicznego (dusza popędliwa, bojowa i rozumna). R. Rohr, A. Ebert, Enneagram: dziewięć typów osobowości, tłum. z ang. A. Kleszcz, Kraków 2004. Wiara w to, że można zrozumieć filozofię starożytną poza kontekstem doświadczeń, które są możliwe jedynie w kontekście określonej praktyki coachingowej jest jednym z mitów filozofii uprawianej w modelu scholastyczno-teoretycznym.

8 Jak powiada Hadot, „każde wszelkie ćwiczenie dialektyczne, właśnie dlatego, że jest poddaniem się nakazom Logosu, ćwiczeniem czystej myśli, odwodzi duszę od tego, co materialne, i pozwala jej zwróci się ku Dobru". Zob. P. Hadot, dz. cyt., 18. 
Epiktet, Justyn Męczennik, Klemens Aleksandryjski czy Augustyn?. U pierwszych myślicieli chrześcijańskich termin 'filozofia' jest jeszcze używany w znaczeniu „coachingowym”. Nie odnosi się do systemu wiedzy, lecz do „monastycznego sposobu życia”" ${ }^{10}$. Uprawiać filozofię znaczy w tym kontekście podejmować konkretne praktyczne wysiłki w celu przemiany życia. Ćwiczenia duchowe wypracowane w starożytnych szkołach filozoficznych są częścią systematycznej duchowej praktyki pierwszych chrześcijańskich filozofów. „Uwaga skierowana na siebie, koncentracja na teraźniejszości, myśl o śmierci” - jak pisze Hadot - będą nierozłączne w tradycji monastycznej tak samo, jak w filozofii świeckiej"11. Dla przykładu, systematyczne praktykowanie rachunku sumienia, najlepiej na piśmie, jest wspólnym „coachingowym" dziedzictwem chrześcijaństwa i filozofii greckiej. Orygenes, na przykład, mówiąc o rachunku sumienia, wypowiada się w stylu stoickim: „Ów obrachunek powinien odnosić się do uczuć w duszy i jej działań. Czy ma na celu dobro? Czy poszukuje cnót? Czy czyni postępy? Czy na przykład całkowicie stłumiła swe namiętności: gniew, smutek, lęk albo żądzę sławy? W jaki sposób daje, a w jaki bierze, w jaki ocenia prawdę?"12. Tak jak Epikur czy Epiktet Ojcowie pustyni zalecają ćwiczenia medytacyjne nad mądrościowymi sentencjami mistrzów (apoftegmatami). Pisemnym śladem tych praktyk są

9 Najwyraźniej wśród tekstów Augustyna coachingowy charakter ujawniają jego dialogi filozoficzne. „W ujęciu Augustyna chrześcijaństwo ma właściwie tę samą treść co platonizm: chodzi o to, by odwrócić się od świata zmysłów, by móc kontemplować Boga i rzeczywistość duchową, lecz tylko chrześcijaństwo potrafiło sprawić, że taki sposób życia przyjęły masy". P. Hadot, Czym jest filozofia starożytna?, tłum. z fr. P. Domański, Warszawa 2000, 314. Sokratejski styl filozoficznych dialogów Augustyna ustępuje stopniowo Arystotelesowskiemu stylowi prac późniejszych.

10 „Filozofia” od tej pory oznaczać będzie właśnie monastyczny sposób życia jako doskonałość życia chrześcijańskiego; ale ta „filozofia” będzie cały czas ściśle związana z kategoriami świeckimi, takimi jak pokój duszy, brak namiętności, „kierowanie się rozwagą i postępowanie zgodne z naturą". P. Hadot, Czym jest filozofia starożytna, dz. cyt., 303.

11 Tamże, 304.

12 Tamże, 302. 
apoftegmaty ojców pustyni, ale też słynne Żywoty Diogenesa Laertiosa. Tak samo jak Platoński Sokrates pierwsi myśliciele chrześcijańscy (np. Ewagriusz z Pontu, Porfiriusz czy Grzegorz z Nazjanzu) traktują filozofię jako praktyczne ćwiczenia służące opanowaniu pożądań i praktykowaniu cnót.

Coachingowy styl filozofowania, po swoim rozkwicie w okresie klasycznym i renesansie w filozofii „monastycznej”, stopniowo zanikał w filozofii Zachodu, ustępując miejsca modelowi naukowo-teoretycznemu. Ilustracją zmian modelu uprawiania filozofii może być historia logiki. Dyscyplina ta narodziła się jako jeden ze składników systemu zajęć praktycznych służących uprawianiu „ogrodu duszy”. U Epikteta logika jest „dyscypliną przyzwolenia”"13, która bardziej przypomina współczesną terapię opartą na logice niż dyscyplinę akademicką. Logika Epikteta polega przede wszystkim na ćwiczeniu się w „czystości myślenia”. Uczenie się logiki nie ma polegać na zaznajamianiu się z sylogizmami i ćwiczeniu stosowania abstrakcyjnych reguł wnioskowania, ale na rozwijaniu umiejętności dostrzegania we własnym myśleniu elementów pozaracjonalnych, motywowanych "patologicznymi" 14 emocjami, a nie logiką zdarzeń ${ }^{15}$. Epiktet nie odrzuca całkowicie logiki, rozumianej jako wiedza teore-

13 „Dyscyplina przyzwolenia nakazuje przyjmować tylko przedstawienia obiektywne; ale obiektywne są jedynie fizyczne wyobrażenia rzeczy, czyli sądy, za pomocą których przypisujemy rzeczom ich prawdziwe cechy, ich cechy naturalne - a więc »fizyczne « zamiast fałszywych, będących tylko odbiciem ludzkich namiętności i umowności (...)”. P. Hadot, Filozofia jako ćwiczenie duchowe, dz. cyt., 173.

14 Warto zwrócić uwagę na fakt, że słowo 'patologiczny' we współczesnej polszczyźnie (podobnie jak w innych językach europejskich) ma bardziej medyczne niż filozoficzne konotacje. Kojarzy nam się z odstępstwem od normy „zdrowego funkcjonowania”, bardziej niż z działaniem nieuważnym, mechanicznym, wykonywanym bez wewnętrznego poczucia sensu. Greckie terminy pathos i logos odsyłają nas jednak do innego rozumienia.

15 Z logiką zdarzeń, wedle stoików nie należy się spierać, lecz bez reszty ją zaakceptować. Kluczowa trudność w rozumieniu charakteru stoickiej logiki dla współczesnego czytelnika polega, po pierwsze, na odmiennej perspektywie psychologicznej: stoicy uznają, że najwyższa część duszy, hegemonikon, nie jest uwikłana w splot zdarzeń fizycznych oraz, po drugie, na „teologicznej” fizyce: za pojęciem „logiki zdarzeń”, kryje się wiara w splatający 
tyczna - dostrzega sens zaznajamiania uczniów z teorią rozumowań (ich znajomość może się przydać „aby nas kto nie zwiódł pozornym sylogizmem”) - ale ostrzega przed nadmiarem wiedzy teoretycznej, która w oderwaniu od codziennie praktykowanej dyscypliny sądzenia jest niepotrzebnym balastem i „czczym popisem”. Aspekt coachingowy logiki jest dla niego pierwotny i zdecydowanie ważniejszy niż teoretyczny. Uczenie się logiki w źródłowym, stoickim znaczeniu tego słowa jest - mówiąc obrazowo - rodzajem „coachingu przekonań”. Nauczyciel logiki wchodzi w osobową relację ze swoim uczniem, staje się towarzyszem podróży „małego logosu” (jednostkowego rozumu) do świata Logosu powszechnego. Podobnie Platońska dialektyka, nie jest zbiorem abstrakcyjnych reguł wnioskowania, lecz praktyką dobrej rozmowy ${ }^{16}$, która ma prowadzić do odrzucenia „pato-logicznych” struktur myślowych i zwrócenia się ku Dobru. W trakcie takiej rozmowy adepci stoicyzmu dokonywali wglądów, które zmieniały ich myślenie, podobnie jak to ma miejsce dzisiaj w trakcie udanych sesji coachingowych. Logika stoicka, tak jak Platońska dialektyka, to przede wszystkim zespół prowadzonych pod kierunkiem nauczyciela ćwiczeń, których celem jest porzucenie przekonań destrukcyjnie wpływających na jednostkę, wyciszenie umysłu i przygotowanie go do kontemplacji, słowem przemiana umysłu - metanoia.

Filozofowie średniowieczni korzystają ze starożytnej logiki głównie w postaci Arystotelesowskiego Organonu, ale przejmują też grecką ideę Logosu, która za sprawą św. Jana nabiera wyrazistego, uświęconego autorytetem Ewangelii duchowo-teologicznego znaczenia. Dzięki temu myśl grecka znajduje w filozofii chrześcijańskiej niejako swoje wypełnienie. Ujmowana od strony praktycznej filozofia Ojców Kościoła jest kontynuacja greckich ćwiczeń duchowych. Przejawia

zdarzenia Rozum Powszechny. P. Hadot, Twierdza wewnętrzna. Wprowadzenie do „Rozmyślań” Marka Aureliusza, tłum. z fr. P. Domański, Warszawa 2004, 124.

16 Można przypuszczać, że „dobra rozmowa” była ćwiczeniem praktykowanym w Akademii. Rozmówcy stawali się dla siebie lustrem, w którym można było dostrzec niezgodne z Logosem przekonania. 
się to nie tylko w uniwersalizmie myślenia wczesnochrześcijańskiego, związanym z ontologicznym wymiarem pojęcia Logosu, ale też w na wskroś racjonalnym ${ }^{17}$ charakterze ich praktyki filozoficznej. Jak powiada Justyn, „ci, co wiedli życie z Słowem [Logos] zgodne, są chrześcijanami, chociażby uchodzili za ateuszów, jak na przykład wśród Greków Sokrates, Heraklit i do nich podobni"18. Ćwiczenia dialektyczne w średniowieczu były kontynuacją Platońskiego coachingu filozoficznego. Powiedzenie „filozofia służebnicą teologii” ujęte od strony praktyk duchowych można przetłumaczyć jako twierdzenie, że dialektyka jest przygotowaniem umysłu do kontemplacji. Nie chodziło o ćwiczenie kompetencji retorycznych samych w sobie, lecz, zgodnie z Augustyńską wykładnią, o wykorzystywanie dyskusji jako narzędzia uwrażliwiania się na głos wewnętrznego Nauczyciela, o kształtowanie postawy modlitewnej uwagi, która jak powiada Simone Weil, jest podstawą wszelkiego edukacyjnego sukcesu.

Filozofia w średniowieczu specjalizuje się i profesjonalizuje. Procesom tym sprzyjało odejście oficjalnej filozofii chrześcijańskiej od Platona w stronę Arystotelesa oraz jurydyzacja nie tylko filozofii, ale też praktyki i etyki chrześcijańskiej. Filozofia była też coraz częściej traktowana jako narzędzie walki doktrynalnej. Tak opisuje uniwersytety XV wieku profesor uniwersytetu krakowskiego Jakub z Paradyża: „Na uniwersytetach przykładają się najbardziej do siedmiu sztuk wyzwolonych, gdzie ćwiczą się w skomplikowanych sofizmatach, w sylogizmach, roztrząsają sprawę powszechników, pierwszych zasad bytu, cech określających tożsamość rzeczy, poznają filozofię naturalną i moralną, prawo rzymskie i kanoniczne, sztukę medycyny i inne nauki, które, jak wiadomo, służą ogładzie doczesnego życia. Ćwiczą się w końcu również w zakresie świetności mowy i subtelności wyrażeń.

17 Ćwiczenia filozoficzne w tradycji grecko-chrześcijańskiej różnią się w tym względzie od praktyk duchowych hinduizmu, gdzie dużą wagę przykłada się np. do ćwiczeń oddechowych. Wyróżniającą cechą tej tradycji jest też traktowanie dialogu filozoficznego jako ćwiczenia duchowego. Por. np. D. Calouri, Plotinus on the Soul, Cambridge 2015, 168.

18 Justyn, Apologia, I, 46, 3, cyt. za: P. Hadot, Czym jest filozofia starożytna, dz. cyt., 301. 
Ale biada! Niewielu widzimy, którzy poświęcaliby swe troski i siły w ulepszaniu obyczajów, życiu cnotliwemu" 19 .

Procesy „scholastyzacji”, o których tu mowa, nie dotyczą tylko filozofii chrześcijańskiej uprawianej w szkołach, czyli tzw. scholastyki, która, co warto podkreślić, często kładła większy nacisk na rozwijanie i trening kompetencji duchowo-intelektualnych adeptów filozofii niż jej renesansowi krytycy. Wyrazem scholastyzacji jest przede wszystkim koncentrowanie się na wytworach myśli, tzn. na gotowych twierdzeniach, zamiast na doświadczeniu, a także przesadne akcentowanie indywidualnego autorstwa twierdzeń filozoficznych. W tym sensie renesansowi krytycy filozofii scholastycznej są często bardziej scholastyczni niż tacy scholastycy, jak Tomasz czy Bonawentura, dla których osobiste autorstwo teorii filozoficznych było kwestią całkowicie pozbawioną znaczenia. Paradoksalnie, właśnie w renesansie, okresie walki ze scholastyką, punkt ciężkości przesuwa się z praktyk i ćwiczeń duchowych w stronę zobiektywizowanych doktryn, które definiują „filozofie” ich autorów. Ponadczasowa mądrość wyrażająca się w jednej philosophia perennis ustępuje miejsca mnogości koncepcji, kojarzonych z nazwiskami ich autorów.

Towarzyszą temu znaczące zmiany pojęciowe. Zmienia się przede wszystkim rozumienie czasu przez filozofów. „Wieczne teraz”, Boecjuszowe nunc stans, redukuje się stopniowo do indywidualnie przeżywanej aktualnej chwili czasu zegarowego. Pojmowanie czasu jako wiecznego „teraz” jest typowe dla doświadczenia kontemplacyjnego, które jest centrum i punktem odniesienia myślenia klasycznego, a przynajmniej nurtu platońskiego i neoplatońskiego. Myślenie nowożytne przebiega tak, jakby istniał tylko czas fizyczny, a atemporalne nunc stans było jedynie konstrukcją jednostkowego umysłu ${ }^{20}$.

19 Jakub z Paradyża, De triplici genere hominum, cyt. za: J. Stoś, Krytyka metody scholastycznej oraz schola mystica w pismach Jakuba z Paradyża, Studia Philosophiae Christiane 36(2000)2, 246.

20 U Boecjusza w trwającym aspekcie „tu i teraz” przejawia się wieczność: nunc stans facit aeternitatum. 
Uniwersalizm w nowożytnym rozumieniu opiera się na wyartykułowanych językowo prawach i traci z pola widzenia Rozum powszechny. Pojęcie recta ratio, czyli stoickie orthos logos, odnosi się teraz do jednej z „naturalnych” własności intelektu ludzkiego ${ }^{21}$. Filozofia usytuowała się w obszarze myślenia dyskursywnego, dianoetycznego i zaczęła być utożsamiana $\mathrm{z}$ wygłaszaniem i obroną poglądów, a nie z praktyką Platońskiej „dobrej rozmowy” czy „monastycznym” sposobem życia.

$\mathrm{W}$ epoce nowożytnej filozofia uprawiana w modelu coachingowym zniknęła w zasadzie $\mathrm{z}$ głównego nurtu kultury europejskiej. Twórczość Kierkegaarda czy Nietzschego można potraktować jako dziewiętnastowieczne próby ożywienia niescholastycznego ducha filozofii starożytnej, kontynuowane przez Heideggera, Sartre'a, Marcela czy Bubera. Podobnie można też odczytywać filozofię Wittgensteina, w którego pismach pojawia się rodzaj mistycyzmu „tu i teraz"22, a także językowa „terapia” filozoficzna. Jednak już z samego faktu, że wymienione postacie kojarzymy z przypisywanym jednostce zespołem poglądów, a nie $\mathrm{z}$ rodzajem praktyk, ćwiczeń czy sposobem życia, można wnosić, że nie mamy tu do czynienia z realną zmianą modelu uprawiania filozofii, lecz z poszukiwaniem idei filozofii praktycznej w ramach modelu scholastycznego. Kiedy na początku ubiegłego stulecia ostatecznie oddzieliła się od niej psychologia, filozofia

21 Jak pisze Andrzej Maryniarczyk, w „nowożytności rozpoczęła się redukcja rozumienia recta ratio do naturalnej właściwości intelektu, który w ten sposób został uposażony przez wolę Bożą (recta ratio per essentiam per se recta est - F. Suárez, De legibus, II 2, n. 8, II 5, n. 12 i n.). Kolejnym etapem redukcji rozumienia recta ratio było odnoszenie jej do indywidualnych własności rozumu ludzkiego jako tzw. facultas infallibilis (Th. Hobbes), a także do określenia prawa i reguły logicznego rozumowania. W tym duchu zdefiniował tego typu właściwość intelektu Ch. Thomasius, jako „sprawność naturalnego rozumowania, czyli wyprowadzania prawdziwych wniosków z prawdziwych pierwszych pryncypiów" (facultas naturalis ratiocinandi seu veras conclusiones ex veris primis principiis deducendi - $\mathrm{Ch}$. Thomasius, Institutiones iurisprudentiae divinae, F 1688, III 1, II). Zob. A. Maryniarczyk, Recta ratio, w: Powszechna encyklopedia filozofii, t. 8, red. A. Maryniarczyk, Lublin 2007.

22 Hadot zestawia mistycyzm Wittgensteina z mistyką i teologią apofatyczną Plotyna. Por. P. Hadot, Filozofia jako ćwiczenie duchowe, dz. cyt., 248. 
już od dawna przestała mieć charakter systematycznie prowadzonej praktyki duchowej. Model scholastyczno-teoretyczny stał się powszechnie uznanym i do niedawna ${ }^{23}$ jedynym sposobem uprawiania filozofii na zachodnich uniwersytetach. Do filozoficznej tradycji coachingowej z powodzeniem sięgnęli natomiast w swojej praktyce psychologowie i terapeuci. Wyrazistymi tego przykładami są Wiktor Frankl i Albert Ellis.

\section{COACHING FILOZOFICZNY JAKO LOGOTERAPIA}

W psychologii XX wieku silną pozycję zdobyły nurty naturalistyczne: behawioryzm i freudowska psychoanaliza. Behawioryzm był odpowiedzią na potrzebę unaukowienia psychologii, psychoanaliza psychoterapii. Naukowa psychologia w rozumieniu behawiorystów miała polegać na poszukiwaniu obserwowalnych regularności, bez dążenia do ich wyjaśnienia w terminach struktur nieobserwowalnych. Z kolei freudowska psychoanaliza pozwalała wyjaśniać obserwowalne przejawy ludzkiej psychiki przez postulowanie ich nieobserwowalnych bezpośrednio przyczyn (libido, superego). Oba te kierunki, każdy na swój sposób, kwestionują wartość doświadczenia wewnętrznego ${ }^{24}$, a co za tym idzie wartość filozofii jako ćwiczenia

23 W latach siedemdziesiątych pojawiają się pierwsze próby wykorzystania filozofii akademickiej jako alternatywy dla tradycyjnego doradztwa psychologicznego. Najpierw Peter Koestenbaum w Stanach Zjednoczonych i Gerd Achenbach w Niemczech, a następnie Lou Marinoff w Stanach Zjednoczonych i Michel Weber w Belgii, a w Polsce Lech Ostasz czy Tomasz Femiak. Na Uniwersytecie Śląskim powstał pierwszy w Polsce kierunek Doradztwo filozoficzne i coaching. Na Uniwersytecie Opolskim w 2016 otwarto kierunek studiów Coaching filozoficzny, a od 2015 roku działa Pogadalnia filozoficzna, http://pogadalnia.pl/

24 Co ciekawe, Freud stworzył podstawy psychoanalizy w oparciu o doświadczenie wewnętrzne. Stosował analizę własnych snów, analizował własne przeżycia. Co wieczór wykonywał coś w rodzaju ćwiczenia duchowego - poświęcał czas na analizę własnych doświadczeń i uczuć. Jednak odmawiał wiarygodności doświadczeniom wewnętrznym niezanalizowanych pacjentów. Por. E. Jones, The life and work of Sigmund Freud, New York 1953-57. 
duchowego. Wiarygodną wiedzę o człowieku można według tych szkół zdobyć jedynie z perspektywy zewnętrznej. Behawioryzm opiera to przekonanie na racjach o charakterze metodologicznym: poznanie musi mieć charakter intersubiektywnie sprawdzalny, psychoanaliza - ontologicznym: to, co w subiektywnym doświadczeniu pacjenta może jawić się jako przeżycie duchowe, z punktu widzenia psychoanalityka jest obiektywnym faktem psychologicznym wynikającym z biologicznych uwarunkowań ludzkiej psyche.

Metodologiczny naturalizm nurtów o nachyleniu behawiorystycznym oraz ontologiczny naturalizm psychoanalizy doprowadził do odhumanizowania oraz medykalizacji psychoterapii. Psychoterapię definiowano jako diagnozowanie zaburzeń i przywracanie homeostazy, zdrowie psychiczne ujmowano w terminach „dobrego funkcjonowania", a potrzeby wyższego rzędu wyjaśniano, odwołując się do motywów biologicznych. Wiktor Frankl był jednym z pierwszych psychoterapeutów dostrzegających niebezpieczeństwa "naturalizowania" psychoterapii. Kierunek, jaki nadał on myśleniu o relacji psychoterapeuta-pacjent, a także jego niefizykalistyczna antropologia jest zbieżna $z$ prezentowaną tu ideą coachingu filozoficznego. W podejściu Frankla rozmówca-pacjent jest partnerem Sokratejskiego dialogu, a nie jednostką, której chorobę należy zdiagnozować i wyleczyć. Pacjent Frankla jest przede wszystkim osobą, o której zakłada się, że posiada wewnętrzne zasoby pozwalające jej samodzielnie mierzyć się z jej egzystencjalnymi bolączkami. Problemy te, zamiast jako zaburzenia funkcjonalne, interpretuje się jako wyzwania, zaproszenia do rozwoju. „Psychoterapię głębi”, redukującą człowieka do wymiarów biologicznych, Frankl zastępuje „psychoterapią wysokości”, odwołującą się do jego osobistego rozumienia znaczenia swojej sytuacji życiowej, jego poczucia wolności czy „woli sensu”25.

25 V. Frankl, The Unheard Cry for Meaning, New York 1979, 79. 
Człowiek wg Frankla funkcjonuje w trzech wymiarach: fizyczno-fizjologicznym, psychologiczno-społecznym i duchowo-noetycznym $^{26}$. Ten trzeci to wymiar typowo ludzkich odniesień, związany $\mathrm{z}$ relacjami osobowymi, z tworzeniem planów życia, odczuwaniem sensu, wolności i odpowiedzialności, jest obszarem, gdzie koncentruje się oddziaływanie logoterapeutyczne ${ }^{27}$. Frankl zauważył, że frustracje, z którymi ma do czynienia człowiek współczesny, mają bardzo często charakter egzystencjalny i wypływają z zaburzeń sfery noetycznej. Człowiekowi współczesnemu często dokucza nuda, pomimo wielości rozrywek - poczucie osamotnienia, pomimo mnogości kontaktów - zagubienie w sferze wartości oraz poczucie bezsensu życia. W płaszczyźnie psychologicznej objawia się to w postaci obniżenia ogólnej dynamiki życia i stopnia jego akceptacji, zanikanie motywacji do życia i chęć ucieczki od życia. Psychoterapia zajmująca się tymi trudnościami w oderwaniu od sfery duchowo-osobowej, jest leczeniem objawów z pominięciem przyczyn.

Frankl opracował zespół metod, takich jak dialog Sokratejski, intencja paradoksalna czy derefleksja, które definiują praktykę klasycznej28 logoterapii, ale mogą być też stosowane jako narzędzia coachingu filozoficznego. Logoterapeuta, podobnie jak coach, nie koncentruje się bowiem na uzdrawianiu zaburzonych emocji pacjenta,

26 W wymiarze fizycznym życie ludzkie jest regulowane przez potrzeby biologiczne, takie jak głód, seksualność, ruch; w wymiarze psychicznym przez potrzebę realizacji indywidualnych skłonności (przeżywaną jako przyjemność), w sferze duchowej szuka sensu, sprawiedliwości, wiary i miłości. Por. A. Längle, Analiza egzystencjalna - poszukiwanie zgody na życie, Psychoterapia (2003)2, 37.

27 K. Popielski, Koncepcja logoteorii V. E. Frankla i jej znaczenie w poradnictwie psychologiczno-pastoralnym, w: Wybrane zagadnienia z psychologii pastoralnej, red. Z. Chlewiński, Lublin 1989, 92.

28 Nazwa „klasyczna” logoterapia odnosi się do jej Franklowskiego rozumienia. Współczesna logoterapia większą uwagę przykłada do diagnozy oraz odchodzi od ontologicznego rozumienia sensu na rzecz pojęcia sensu egzystencjalnego. Por. A. Längle, Gdy rodzi się pytanie o sens. Praktyczne zastosowanie logoterapii, tłum. z niem. A. Grzegorczyk, Warszawa 2016, 67-78. 
lecz na jego rozwoju w sferze osobowej. Głównym motywem tych technik jest uwolnienie klienta od autodestrukcyjnych przekonań oraz takie towarzyszenie rozmówcy, poprzez uważne słuchanie i zadawanie pytań, by ten sam dostrzegł i zrozumiał wyzwania jakie stawia przed nim życie, uświadomił sobie swoje prawdziwe wartości, określił swoje cele i dokonał świadomych egzystencjalnych wyborów.

Frankl pełnymi garściami czerpie $\mathrm{z}$ tradycji filozoficznej, nadając jednak swojej recepcji filozofii wyraźne nachylenie coachingowe. Można wskazywać na teorie Nikolaia Hartmanna, Maxa Schelera czy Martina Heideggera jako źródła inspiracji Frankla, jednak historia filozofii, rozumiana jako historia doktryn, nie jest właściwym kontekstem dla rozumienia jego filozofii człowieka. Jego antropologia nie ma charakteru teoretyczno-scholastycznego. Wyrasta z praktyki i służy praktyce logoterapeutycznej. Poza tym kontekstem teoria ta jest zbiorem pustych abstraktów. Jak to ujął Whitehead, teoria jest użyteczna, kiedy wyrasta $z$ doświadczenia, pozwala rozumieć doświadczenie i służy pogłębianiu i wysubtelnianiu przyszłego doświadczenia. Ujmowane w oderwaniu od praktyki koncepcje te, mogą co najwyżej stanowić przedmiot zainteresowania historyka filozofii, lecz ich sens staje się jawny dopiero w kontekście praktyki logoterapuetycznej.

Podobnie jak metafory zawarte w dialogach Platona, antropologia przestrzenna Frankla jest raczej zbiorem narzędzi budzenia doświadczenia noetycznego, niż usystematyzowanym zbiorem twierdzeń składających się na jakąś doktrynę filozoficzną. Podstawowym narzędziem Franklowskiej logoteorii jest metafora. Na przykład metafora „rzutowania”: tak jak szklanka rzutowana na płaszczyznę może dać obraz koła lub prostokąta, zależnie od tego, w jakiej płaszczyźnie wykonamy rzut, zjawiska z obszaru duchowego mogą prowadzić do pozornie niezgodnych ze sobą obrazów klinicznych. Tak jak szklanka rzutowana na płaszczyznę traci swoją otwartość, człowiek ujęty w perspektywie biologicznej może jawić się jako system zamknięty, choć cechuje go otwartość wyrażająca się w samotranscendencji. 
Metafora wyprowadza nas poza wąskie rutynowe rozumienie doświadczenia, w kierunku sensu ukrytego poza zjawiskami. Kieruje naszą uwagę na fakt, że rzeczywistość jest zawsze bogatsza od swoich aktualnie obserwowalnych przejawów. Frankl podobnie jak Platon (np. w metaforze linii) używa pojęć matematycznych dla zobrazowania zjawisk i relacji z obszaru noetycznego, wykraczających poza możliwości jednoznacznego opisu. I podobnie jak to ma miejsce w przypadku dialogów Platona, antropologiczne „teorie” Frankla należy odczytywać w kontekście jego praktyki „leczenia dusz”. Obaj ci autorzy nie są zainteresowani powiększaniem zasobów abstrakcyjnej wiedzy filozoficznej, ale praktyką, jak to proponuję nazywać w tym tekście, „filozoficznego coachingu”.

Jednym z narzędzi Franklowskiej antropologii jest model koncentryczny, który bardzo przypomina macierz ontologiczną jaką opisuję w tekście Filozofia tu i teraz. Filozofia procesu jako podstawa filozoficznego coachingu. Oba modele opierają się na dwu nakładających się trójpodziałach, które dają w efekcie dziewięć obszarów, symbolizujących różne aspekty ludzkiej psyche. U Frankla obrazem struktury psychiki człowieka są trzy współśrodkowe okręgi. Centrum zajmuje wymiar duchowy, następnie psychiczny a najbardziej zewnętrzny okrąg wyznacza granice obszaru cielesnego. Przy czym każde zjawisko $\mathrm{z}$ tych obszarów może występować na poziomie nieświadomym, przedświadomym i świadomym.

Ważnym składnikiem tego modelu jest wyodrębnienie w strukturze ontologicznej człowieka nieświadomej duchowości. W przeciwieństwie do nurtów naturalistycznych (psychoanalizy i behawioryzmu) Franklowska nieświadomość jest obszarem przejawiania się transcendencji. Człowiek może nie być świadomy istnienia swojego wymiaru duchowego ${ }^{29}$, jednak proces terapii lub sytuacje graniczne,

29 Frankl jest autorem „empirycznego” argumentu na istnienie wyższego, duchowego wymiaru ludzkiej psychiki. Jako więzień obozu koncentracyjnego zaobserwował, że to nie tężyzna fizyczna i spryt decydowały o przetrwaniu w nieludzkich warunkach obozu śmierci, lecz 
jak przekonuje Frankl, ujawniają często obecność czegoś, co nazywa „duchową nieświadomością" (w przeciwieństwie do Freudowskiej nieświadomości, którą można nazwać „biologiczną”). Jego zdaniem „człowiek zawsze, choć niekiedy nieświadomie, kieruje się ku Bogu i pozostaje, jeśli nawet $w$ nieświadomym to wirtualnym odniesieniu do Boga" ${ }^{30}$. W trakcie terapii osób, w których świadomym życiu nie było miejsca dla przeżyć religijnych, ujawniały się często bardzo głębokie przeżycia związane $\mathrm{z}$ sacrum.

Ontologiczna orientacja logoterapii Frankla, a w szczególności jego koncepcja Boga jako sensu ontologicznego, jest przedmiotem krytyki ze strony Alfrieda Länglego, rozwijającego egzystencjalną wersję logoterapii. Aby dokonać egzystencjalnego zwrotu w swoim życiu, zdaniem Länglego, potrzebujemy przejść od „rozważania sensu ontologicznego" (przykładem pytań o sens ontologiczny są pytania "dlaczego cierpię na tę chorobę?”, „dlaczego mam ten problem?”) do podjęcia „wyzwania egzystencjalnego („co teraz z tym zrobię?”) ${ }^{31}$. Franklowski sens, zdaniem Länglego jest zbyt „teologiczny”. „Logoterapeutyczne rozumienie sensu dla mniej religijnie nastawionych osób staje się pozbawione emocji, zimne a w swych uzasadnieniach czysto kognitywne"32. We Franklowskim ujęciu sensu, jak powiada Längle, Bóg stoi na początku, w ujęciu egzystencjalnym to wartości pozwalają ukierunkować życie na sens, a Bóg dostępny jest dopiero na końcu.

Krytyka Länglego skierowana przeciw wprowadzaniu do psychoterapii pojęć filozoficznych, jest o tyle słuszna, o ile pojęcia te są oderwane od doświadczenia Klienta i wprowadzane w trybie

„siła ducha”, która wyrażała się w zdolności do znoszenia cierpienia wyrastającej z wiary w jego sens. Por. V. Frankl, Człowiek w poszukiwaniu sensu, tłum. z niem. A. Wolnicka, Warszawa 2013.

30 Wypieranie tej sfery ze świadomości można porównać do mechanizmów wyparcia opisanych przez Freuda w odniesieniu do doznań seksualnych. K. Popielski, dz. cyt., 88.

31 A. Längle, dz. cyt., 44.

32 Tamże, 78. 
scholastycznym. Kiedy jednak w duchu coachingowym proponuje się na przykład pacjentowi do samodzielnej interpretacji nie gotowe doktryny, lecz na przykład metafory, których celem jest obudzenie osobistego doświadczenia wymiaru duchowego, krytyka ta nie wydaje się trafna. Poza tym, z punktu widzenia filozofii procesu, doświadczenie wartości jest w pewnym sensie również doświadczeniem Boga, w którym są one bytowo zakorzenione. Różnica w podejściu Frankla i Länglego w praktyce sprowadza się do szerszego, bardziej systematycznego uwzględniania przez analizę egzystencjalną wymiaru psychopatologii, co zbliża nieco Langlowską analizę egzystencjalną do klasycznego podejścia psychodynamicznego.

W ujęciu egzystencjalnym Länglego rozmowa logoterapeutyczna posiada rytm wyznaczany przez cztery fazy odpowiadające strukturalnym poziomom egzystencji. Zaburzenia ujawniające się na każdym z tych poziomów odpowiadają różnym poziomom dysfunkcji psychicznych. Faza opisu to etap wstępny, gdzie logoterapeuta przysłuchuje się historii pacjenta, ustala fakty. W przypadku Klienta z zaburzeniami psychotycznymi już tutaj następuje zrywanie narracji, pojawiają się perseweracje i niemożność przejścia do kolejnych faz procesu. W kolejnej fazie, fazie wrażenia, rozmowa logoterapeutyczna prowadzi w stronę emocji, jakie rodzą opisywane zdarzenia, nie zatrzymując się jednak na tym poziomie (nie chodzi tu o poszukiwanie źródeł zaburzeń emocji w dzieciństwie). Trzymanie się tego poziomu przez pacjenta, niemożność przekroczenia uwikłań emocjonalnych lub niezdolność do ich adekwatnego przeżywania może wskazywać np. na depresję endogenną lub inne poważne dysfunkcje w sferze emocji. (W przypadku zatrzymania się pacjenta w tych pierwszych fazach rozmowy, logoterapeuta czy coach filozoficzny powinien zaproponować Klientowi inne rodzaje terapii). W fazie postawy pacjent formułuje swoje stanowisko wobec przeżywanych zdarzeń, ujawnia swoje przekonania, „definiuje tożsamość”, dostrzega różnicę pomiędzy odniesieniem emocjonalnym a przekonaniami. Zatrzymanie na tym poziomie, trudność oddzielenia emocji od przekonań 
wskazuje na możliwe zaburzenia osobowości. Zaburzenia tego rodzaju związane na przykład z narcystycznymi, histrionicznymi czy paranoicznymi cechami osobowości o niewielkim nasileniu są bardzo typowymi objawami, szeroko rozpowszechnionymi w społeczeństwie i nie wykluczają prowadzenia logoterapii czy coachingu filozoficznego. Poziom czwarty to poziom ekspresji, gdzie następuje przejście do aktywnego poszukiwania rozwiązań. Dopiero tu uaktywnia się „filozoficzny” wymiar poszukiwania sensu.

Aby móc przeżywać życie jako sensowną całość, osoba ludzka, według Länglego musi spełniać cztery warunki pełnej egzystencji. Można je odnieść do powyższych czterech faz rozmowy. Są to niejako cztery poziomy wewnętrznego przyzwolenia, wewnętrznej zgody, jakiej udzielamy światu i sobie. Po pierwsze, jest to zgoda na rzeczywistość wyrażająca się w przeżywaniu świata jako miejsca akceptowanego, zdolnego zaspokoić nasze podstawowe potrzeby. Po drugie, jest to przyzwolenie na odczuwanie, wyrażające się w doświadczaniu życia jako czegoś pozytywnego, jako procesu, w który chcemy się włączyć. Po trzecie jest to zgoda na siebie jako osobę, którą jesteśmy, dokonując świadomych wyborów, pozostając w zdrowym dystansie wobec innych osób i opowiadając się za określonymi wartościami. Wreszcie, po czwarte, jest to zgoda na sens, jaki odkrywamy w naszym życiu. Dopiero na tym ostatnim poziomie - metapoziomie, czyli innymi słowy: poziomie refleksji filozoficznej nad własnym życiem - możemy ująć swoje życie jako całość i, parafrazując Länglego, próbować uchwycić sens egzystencjalny jako sens ontologiczny.

Jednym z zagrożeń, jakie może nieść praktyka źle rozumianego coachingu filozoficznego, jest traktowanie zaburzeń na niższych poziomach funkcjonowania jako problemów sfery noetycznej. Redukowanie wszystkich dysfunkcji do problemów związanych z rozumieniem sensu jest równie jednostronne i niebezpieczne jak biologizm redukujący je wszystkie do kwestii „fizjologicznych”, związanych np. z dysfunkcją odpowiednich obszarów mózgu. Filozofowie, nota bene, wydają się szczególnie narażeni na błąd intelektualizowania, 
wyrażający się w próbach opisywania problemów Klienta w kategoriach zobiektywizowanego sensu ontologicznego. Sens ontologiczny nie może oczywiście zastąpić sensu egzystencjalnego odnajdywanego przez Klienta w jego własnym sumieniu. Coach filozoficzny może pomóc klientowi dostrzec sprzeczności w jego obrazie Boga czy Przyrody, lecz nie może przekazywać mu gotowych, przez siebie dostrzeganych sensów. Jego rola jest stworzyć przestrzeń, w której klient może odkrywać swoje osobiste rozumienie.

Klasyczne podejście Franklowskie jest, podobnie jak coaching, ukierunkowane na przyszłość, nie zatrzymuje się na poziomie „uzdrawiania zranień", jest skoncentrowane na pozytywnie formułowanych celach i odwołuje się do pojęcia sumienia, które jest, jak powiada Frankl, „organem odkrywania sensu”. Franklowska analiza sumienia przekracza poziom psychologiczny wkraczając w sferę noologiczną, czyli sferę logosu, którego nie można sprowadzać jedynie do tego, co uświadomione i racjonalne. Ludzkie sumienie posiada swój aspekt nieświadomy, ale w przeciwieństwie do Freuda nie jest to biologicznie uwarunkowana podświadomość, a raczej wyrażająca ludzką zdolność przekraczania siebie „nieświadomość duchowa” ${ }^{3}$. Lepiej niż określenie 'podświadomość' oddaje, moim zdaniem, sens tego wyrażenia pojęcie 'nadświadomość'.

Dokonując egzystencjalnej analizy sumienia, Frankl odkrywa jego cechę, którą nazywa „transcendencją sumienia”: „wszelka wolność jest wolnością "od czegoś« i »do czegoś«. Tym, od czego możemy być wolni, jest władza popędów, natomiast wolność »do czegoś« jest wolnością do bycia odpowiedzialnym, do posiadania sumienia. Oba aspekty ludzkiej kondycji najlepiej oddaje to oto krótkie napomnienie Marii von Ebner-Eschenbach: »Bądź panem swojej woli i sługą swojego sumienia!."34.

33 V. Frankl, Bóg ukryty, dz. cyt., 84.

34 Tamże, 75. 
Człowiek jest odbiorcą „głosu sumienia”, a nie jego źródłem. Chcąc zrozumieć człowieka w jego osobowej głębi trzeba uznać, że „przez głos sumienia rozbrzmiewa - per sonat - głos jakiejś istoty pozaludzkiej”35. Fakt, iż człowiek współczesny nie traktuje na ogół swojego sumienia jako przestrzeni kontaktu $z$ transcendencją, nie jest skutecznym argumentem na rzecz jego immanentnego charakteru. Rozpoznanie głosu sumienia, jak każda czynność poznawcza, wymaga bowiem pojęć i rozumienia. Frankl, by zilustrować ten fakt, przywołuje biblijną historię Samuela (1 Sm 3,9), który nie potrafi zinterpretować słyszanego we wnętrzu głosu jako głosu Boga, do momentu, gdy jego mistrz Heli nie rozpoznaje jego transcendentnego charakteru i nie przedstawia mu jego religijnej interpretacji. Fenomenologiczna analiza głosu sumienia dokonana przez Frankla prowadzi go do wniosku, że jego źródłem jest pozaludzka siła o charakterze osobowym ${ }^{36}$. Jest to Ktoś, przed kim człowiek jest odpowiedzialny, nawet wtedy, gdy sobie tego nie uświadamia.

Platoński Sokrates nie ma wątpliwości co do transcendentnego źródła słyszanych przez siebie w swoim wnętrzu „głosów”. Nie ma też wątpliwości, że słów daimoniona nie może zignorować, choć, w odróżnieniu od słyszących "głosy" schizofreników, posiada wewnętrzną przestrzeń wolności, w której świadomie decyduje się być im posłuszny. Głos daimoniona nie odbiera Sokratesowi wolności, jest raczej jej stróżem, odzywającym się, gdy niższa część jego osobowości chce nim zawładnąć i uczynić coś, co nie jest jego prawdziwym pragnieniem. Racjonalista Sokrates decyduje się na posłuszeństwo głosowi Boga słyszanemu we własnym wnętrzu, uznając to za swoje powołanie, związane $z$ duchowym centrum swojej osoby, choć niekoniecznie $\mathrm{z}$ ciałem fizycznym. W zestawieniu $\mathrm{z}$ tym osobistym, wewnętrznym „interesem” jego własne biologiczne przetrwanie a nawet dobro najbliższej rodziny muszą zejść na drugi plan. Staje

35 Tamże, 76.

36 Tamże. 
się w ten sposób ikoną, pierwowzorem wszystkich ludzi sumienia. Czy w związku z pozaracjonalnym (bardziej ponadracjonalnym niż irracjonalnym i bardziej nadświadomym niż podświadomym) charakterem sumienia podlega ono racjonalnej analizie? Czy można $\mathrm{w}$ procesie edukacji rozwijać zdolności związane $\mathrm{z}$ funkcjonowaniem sfery noetycznej? Frankl jest przekonany, że tak: „W czasach, w których obecnie żyjemy, w epoce bezsensu, podstawowym zadaniem systemu edukacji powinno być doskonalenie sumienia człowieka wciąż jedynej takiej własności, która pozawala mu odnajdywać sensy w świecie upadających wartości i tradycji - a nie ograniczanie się do zwykłego przekazywania tych tradycji oraz wiedzy"37.

\section{COACHING FILOZOFICZNY JAKO METODA DYDAKTYCZNA}

Filozofia w rozumieniu coachingowym to zbiór ćwiczeń służących wychowaniu dojrzałych, silnych psychicznie, ale też etycznie wrażliwych osobowości. Metody te wykraczają poza ontologiczny naturalizm, nie kłócą się jednak z szeroko rozumianą ideą naukowości jako intersubiektywnej krytykowalności. Poznanie noetyczne odnosi nas do sensu przekraczającego to, co zmysłowo obserwowalne. Jeśli głos sumienia może być interpretowany np. jako głos transcendentnego Boga, a nie tylko wyraz naszego „superego”, musimy przyjąć, że, jak powiada Platon, „poznanie intelektualne i mniemanie prawdziwe są dwoma różnymi rodzajami"38. Poznanie intelektualne odnosi się do rzeczywistości ponadzmysłowej, co nie oznacza, że niewyrażalnej w języku intersubiektywnym. Poznanie to jest intersubiektywnie krytykowalne, choć nie spełnia kryterium naturalizmu ontologicznego. Jednak z podobną sytuacją mamy do czynienia np. w matematyce.

37 Tamże, 147.

38 Platon, Timajos, tłum z gr. P. Siwek, Warszawa 1986, 66. Platon uzasadnia tu istnienie Idei, odwołując się do istnienia poznania intelektualnego. Nie odwrotnie! 
Ćwiczenia tego rodzaju nie są martwym reliktem przeszłości i mogą być elementem kształcenia studentów, w szczególności tych, którzy przygotowują się do pracy coacha lub doradcy filozoficznego ${ }^{39}$. Nadają się też do wykorzystania w pracy z młodzieżą na różnych szczeblach edukacji ${ }^{40}$. Dwa główne wyznaczniki tego podejścia można skrótowo określić jako przeniesienie akcentu $\mathrm{z}$ wiedzy obiektywnej na doświadczenie osobiste oraz uwzględnianie porządku serca, a nie tylko umysłu. Pojęcie serca używam tu nie w potocznym, sentymentalnym znaczeniu, gdzie odnosi się ono do przeżyć emocjonalnych głównie romantycznej natury, lecz w sensie Pascalowskiej ordre du couer czy osobowego centrum człowieka w tradycji monastycznej (serce to w tej tradycji wewnętrzna przestrzeń, w której człowiek doświadcza swojej wolności i zdolności kochania Boga).

Pitagorejskie i Platońskie ćwiczenia duchowe opierały się na założeniu, że filozofia ma uzdalniać do przyjaźni. Współcześnie, w kontekście przemian cywilizacyjnych, które głęboko zaburzają relacje interpersonalne, powinniśmy znów stawiać sobie to jako jeden z głównych celów edukacji. Zajęcia dydaktyczne prowadzone w tym duchu są każdorazowo rodzajem procesu grupowego, gdzie dochodzą do głosu cechy osobiste jego uczestników i następuje ich wzajemne „dostrajanie się" do siebie. Nie polega ono na zespoleniu, np. poprzez naśladowanie lidera (prowadzącego), lecz na odnajdowaniu siebie w ramach grupy. Swobodna ekspresja swojej indywidualności jest możliwa dzięki grupie, ale też jest przez nią najbardziej zagrożona.

39 Doradztwo filozoficzne jako forma mentoringu wymaga bardziej teoretycznych kompetencji niż coaching, stąd opisane tu metody dotyczą głównie tego drugiego.

40 Jestem współautorem opracowanego w tym duchu programu zajęć z logiki dla gimnazjum. Zajęcia mają charakter warsztatu, gdzie jednym z kluczowych elementów jest zbudowanie atmosfery pozwalającej uczniom na swobodną ekspresję w ramach dobrze określonej (istotne jest jej niedyrektywne wprowadzanie - poświecenie czasu na dopracowanie reguł w toku pracy grupowej) struktury filozoficznej dyskusji. Celem głównym zajęć nie jest przekazanie określonego kwantum wiedzy, lecz stymulowanie poznania noetycznego. Zabawy integracyjne, wspólnie rozwiązywane zagadki logiczne i zadania matematyczne mają pobudzać kreatywność i rozwijać kompetencje społeczne. 
Rolą prowadzącego jest stworzenie przestrzeni, w której uczestnicy mogą w bezpiecznej atmosferze konfrontować swoje doświadczenia. Sam ten proces jako rozgrywająca się tu i teraz rzeczywistość spotkania stanowi centralny składnik filozoficznego coachingu. Warsztaty filozoficzne prowadzone w tym modelu mają zatem postać bliższą medytacji dialogicznejej niż grupowej.

Czy zdolność wchodzenia w głębokie relacje z innymi ludźmi jest dyspozycją, która może być rozwijana w toku edukacji? W świetle interpretacji zaproponowanej przez Simon Weil właśnie taki jest duchowy kontekst pitagorejskiej matematyki. Simon Weil, cytuje pitagorejskie powiedzenie „przyjaźń jest równością uczynioną $\mathrm{z}$ harmonii" ${ }^{2}$, podkreślając że pitagorejska harmonia jest jednością przeciwieństw: ,ja-inny” są tak bardzo różni, że mają swoją jedność tylko w Bogu. Podkreśla też, że jedność przyjaźni nie jest jednością zespolenia, gdzie „my” zastępuje relację „ja”-,,inny”. Kiedy mówimy „my” zwykle opisujemy np. relacje osób zespolonych jakąś doktryną lub wspólnym celem. Takich więzi nie można nazwać przyjaźnią, gdyż nie ma tu, jak powiada Weil, „,miejsca gdzie mógłby wślizgnąć się Bóg", brak tu pośrednika w postaci harmonii. Prawdziwa harmonia jest polifoniczna i nie występuje tam, gdzie wszyscy „śpiewają na jedną nutę", jak dobrze wyćwiczony oddział wojska. Przyjaźń wymaga głębokiej wzajemnej akceptacji różnych sposobów śpiewania,

41 Johannes Lotz odróżnia medytację wspólną od medytacji dialogicznej. W tej pierwszej uczestnicy zwykle ustawieni są w tym samym kierunku, w tej drugiej siedzą w kręgu, gdzie „każdy ma okazję dodania czegoś z własnego doświadczenia, które sam wniósł w ten krąg, a do którego zresztą nie musi się wobec wszystkich przyznawać. Oczywiście spotkanie takie wyprowadza człowieka poza własny ograniczony widnokrąg". J.B. Lotz, Wprowadzenie w medytację, tłum. z niem. J. Zychowicz, Kraków 1983, 198.

42 Definicja ta odnosi się najpierw do przyjaźni „pomiędzy Bogiem a Osobami boskimi. Następnie jest to przyjaźń między Bogiem i człowiekiem. Na ostatnim miejscu dopiero istnieje przyjaźń między dwojgiem osób lub wieloma ludźmi”. S. Weil, dz. cyt., 110. 
tj. wzajemnego, głębokiego przyzwolenia na siebie i innych, które rodzi się w przestrzeni uwagi noetycznej ${ }^{43}$.

Rozwijanie poznania intelektualnego w Platońskim sensie od strony praktycznej jest tożsame ze stoicką dyscypliną przyzwolenia i polega na ćwiczeniu nieoceniającego spojrzenia na świat. Przyzwolenie to nie polega na wygodnej bezczynności czy lękliwym wycofaniu się, lecz jest najwyższym wyrazem ludzkiej wolności i, jak to pokazuje Simon Weil, jest zdolnością „nie z tego świata”, domaga się bowiem, najpierw umiejętności oddzielania tego, co od nas zależy, od rzeczy od nas niezależnych i bezwarunkowej akceptacji wszystkiego, co istnieje, a więc przede wszystkim akceptacji matematycznej precyzji Porządku rzeczy. Porządek ten może zachwycać, ale z ograniczonego ludzkiego punktu widzenia wydaje się też niekiedy przerażająco obojętny, a nawet okrutny. Zarówno pitagorejska matematyka, jak i stoicka logika okazują się z tego punktu widzenia rodzajem egzystencjalnej logoterapii, gdzie człowiek uczy się dostrzegać i akceptować wszystkie wymiary swojej egzystencji. Uczy się patrzenia z perspektywy Sensu. „Matematyce wyrządza się krzywdę traktując ją tylko jako racjonalną i abstrakcyjną spekulację. Niewątpliwie jest taką, ale matematyka to także nauka o samej naturze, nauka zdecydowanie konkretna, będąca jednocześnie dziedziną mistyki. Te trzy właściwości występują w matematyce równocześnie i niepodzielnie" 44 .

Podobnie jak Simon Weil, Whitehead to matematyk i filozof $\mathrm{w}$ jednej osobie, który dostrzega potrzebę wiązania w procesie

43 Instytut Filozofii Uniwersytetu Opolskiego realizuje w latach 2017-2019 projekt „Logiczny uczeń" gimnazjum. Zajęcia mają charakter warsztatowy, gdzie pozwala się uczniom na swobodną ekspresję w ramach grupy (istotne jest poświęcenie czasu na dopracowanie reguł w toku pracy grupowej). Celem głównym zajęć nie jest przekazanie określonego kwantum wiedzy, lecz stymulowanie logicznego myślenia w konkretnych praktycznych kontekstach. Zabawy integracyjne, dyskusje, wspólnie rozwiązywane zagadki i zadania logiczne, pobudzają kreatywne myślenie, rozwijają kompetencje społeczne a przede wszystkim pozwalają uczestnikom uaktywniać sferę noetyczną, czyli rozwijać wrażliwość na sferę osobową ludzkiej egzystencji.

44 S. Weil, dz. cyt., 128. 
edukacji kształcenia zdolności dyskursywnych i intuicyjnych. Przeciwstawia się scholastycznemu modelowi edukacji i postuluje rozwijanie doświadczenia noetycznego, które utożsamia z szeroko rozumianym doświadczeniem estetycznym. „Nasza nauczycielska rutyna jest niemal wyłącznie książkowa. (...) Środkiem ciężkości jest tu intelekt a głównym narzędziem drukowana książka. Środkiem ciężkości drugiej strony oświaty winna być intuicja, ale bez analitycznego odseparowania od całościowego otoczenia. Brak nam tego typu myślenia ogólnego, które byłoby w stanie uchwycić różnorodność wartości. Mam na myśli rozwój estetyczny. (...) sztuka to tylko szczególny przypadek. Tymczasem mnie chodzi o ożywienie nawyku estetycznego podejścia do rzeczy" 45 . Cywilizacja techniczna, a także, jak powiada, „materialistyczne podstawy nauki” miała negatywny wpływ na rozwój człowieka w tym wymiarze, kierując jego uwage na „rzeczy w przeciwstawieniu do wartości”. Ludzka tożsamość jest, według Whiteheada, czymś więcej niż trwałością organizmu fizycznego, ,jest życiem ducha. Odnosi się raczej do indywidualizacji działalności twórczej”. Ludzka dusza nie znosi monotonii. „Zmienność nastroju, dowcipu, niepowagi, zabawy snu, jest dla niej koniecznością". Wedle Whiteheada przeżycia estetyczne mają swój wymiar „matematyczny”: dostarczają bezpośredniej radości, ale też „poddają dyscyplinie najbardziej intymną część naszej istoty. Dyscypliny tej nie daje się oddzielić od radości, gdyż z radości się rodzi" 46 .

$\mathrm{W}$ programach zajęć pisanych zgodnie $\mathrm{z}$ Whiteheadowską ideą rytmu edukacyjnego ${ }^{47}$ zabawa nie jest przerywnikiem $w$ ramach tradycyjnie „książkowo” prowadzonych zajęć, ale ich integralną częścią, wchodzącą w skład pierwszej fazy zdarzenia edukacyjnego, zwanej przez Whiteheada fazą romantyczną. Doświadczenia uczestników

45 A.N. Whitehead, Nauka i świat współczesny, tłum. z ang. S. Magala, Warszawa 1988, 205-206.

46 Tamże, 210.

47 A.N. Whitehead, Rythm of education, London 1922. 
zabawy są bazą, na której prowadzący buduje ich część teoretyczną, odnosząc proponowane teorie do zdobytych $\mathrm{w}$ trakcie tej fazy doświadczeń. Ten kolejny etap to faza precyzowania (precision), której zwieńczeniem jest faza nazywana przez Whiteheada, w nieco mylący sposób, fazą uogólniania (generalisation). Jej celem nie jest bowiem przeniesienie zdobytej wiedzy na wyższy poziom abstrakcji, lecz ponowne wiązanie jej z indywidualnym doświadczeniem, poprzez szukanie zastosowań w konkretnych sytuacjach życia. Swój esej na temat edukacji Whitehead kończy w sposób zaskakujący, zważywszy fakt, że nie był wyznawcą żadnej religii: „Istotą edukacji jest jej religijność. Religijność polega na włączaniu obowiązku i nabożności. Obowiązek wyłania się z naszej potencjalnej kontroli nad biegiem zdarzeń. W tym zakresie w jakim wiedza może rozwiązać problem, ignorancja staje się wadą. Nabożność opiera się na dostrzeganiu, że "teraz« zawiera w sobie całą pełnię istnienia, ujmowaną w obu kierunkach czasu, które razem składają się na wieczność"48.

\section{PRZYKŁADY ĆWICZEŃ COACHINGOWYCH W DYDAKTYCE FILOZOFICZNEJ}

W modelu tradycyjnym, omawiając ze studentami jakieś zagadnienie z obszaru na przykład epistemologii, naszym głównym celem jest przedstawienie historii zagadnienia, aktualnego stanu badań i możliwych rozwiązań. Dyscyplina, której nauczamy, jest traktowana jako składnik „wiedzy obiektywnej”, a student jako potencjalny „ekspert” w tej dziedzinie, rozumiejący podstawowe zagadnienia, znający klasyczną literaturę i potrafiący samodzielnie formułować epistemologiczne tezy oraz argumenty na ich rzecz.

Model coachingowy wymaga przesunięcia akcentów z kompetencji eksperckich na rozwojowe. Teksty i zawarta w nich wiedza są traktowane instrumentalnie - są jedynie narzędziem skłaniającym

48 A.N. Whitehead, The Aims of Education and Other Essays, New York 1967/29, 26. 
studentów do odnoszenia się do osobistego doświadczenia, rozpoznawania własnego stylu myślenia oraz krytycznej refleksji nad własnymi sposobami uzasadniania przekonań. Epistemologia uprawiana w tym modelu zawiera ćwiczenia, których celem jest nabycie kompetencji w rozpoznawaniu irracjonalnych składników własnego myślenia.

Przykładem prostego ćwiczenia coachingowego, które można wprowadzić do zajęć z teorii wiedzy, jest ćwiczenie „Wiem, że wiem”. Prowadzący zachęca studentów do wypisania kilku osobistych przekonań, o których mogą oni z przekonaniem powiedzieć, że stanowią ich wiedzę. Kolejnym krokiem jest propozycja indywidualnej pisemnej analizy wskazanych przekonań: zwrócenie uwagi na ich źródła, kontekst, w którym powstały, rolę autorytetu innych ludzi w ich uznawaniu, sposób uzasadniania. Następnie studenci zachęcani są do dzielenia się wynikami. Jest to ważny składnik ćwiczenia, gdyż pozwala dostrzec indywidualny charakter naszych „stylów myślowych”. Prowadzący tego typu zajęcia powinien unikać postawy „eksperckiej”, stwarzając wrażenie, że istnieje jakieś jedno „prawidłowe”, uznane przez ekspertów, rozwiązanie tego zadania. Powinien jednak zachować krytycyzm, dostrzegając wartości pozytywne poszczególnych stylów, lecz zadając też niewygodne pytania w sytuacji, gdy propozycje studentów budzą wątpliwości natury logicznej.

Ważnym składnikiem edukacji filozoficznych coachów jest zdobywanie sprawności w prowadzeniu tzw. terapii opartej na logice (logic-based therapy, LBT). Jej elementy mogą być, podobnie jak wyżej opisane ćwiczenie, wykorzystane w programie zajęć z epistemologii. Celem ćwiczenia „Dlaczego mnie to irytuje?” jest rozwijanie umiejętności dostrzegania we własnym myśleniu elementów irracjonalnych i autodestrukcyjnych. LBT podobnie jak terapia racjonalno-emotywna Alberta Ellisa oraz stoickie ćwiczenia duchowe opierają się na założeniu, że ludzkie emocje mają swe źródło w przekonaniach związanych $\mathrm{z}$ dotyczącymi nas wydarzeniami a nie w samych tych wydarzeniach. Ćwiczenie rozpoczyna rozmowa w parach, w trakcie 
której jedna z osób odgrywa rolę coacha a druga Klienta. Rozmowa dotyczy jakiejś niekoniecznie poważnej, ale rzeczywistej sytuacji, w której pojawiają się emocje (np. irytacja, poruszenie, lęk, przygnębienie). Zadaniem coacha jest zadawanie pytań w taki sposób, aby Klient uświadomił sobie swoje własne przekonania związane $\mathrm{z}$ danym wydarzeniem. Kolejny krok to sformułowanie (najlepiej wypisanie) tych przekonań i zwrócenie uwagi na strukturę wnioskowania, a w szczególności przyjmowane milcząco przesłanki. $\mathrm{Na}$ przykład, „boję się utraty pracy, ponieważ kiedy myślę o sobie jako o człowieku bez pracy, widzę siebie jako przegranego nieudacznika”. Przesłanką tego wnioskowania jest myśl: ,jeśli stracę pracę, będę przegranym nieudacznikiem”. Odkrycie kolejnych ukrytych przesłanek wnioskowania, w postaci na przykład takiego przekonania: „uważam, że powinienem być zawsze doskonały, nie mam prawa popełnić błędu", może być ważnym składnikiem samopoznania osoby biorącej udział w ćwiczeniu. Ćwiczący nie muszą oczywiście ujawniać przed grupą swoich konkretnych osobistych doświadczeń i spostrzeżeń. Podsumowanie tego ćwiczenia ma charakter indywidualny. Jednak warto na bazie doświadczeń i wglądów uzyskanych w toku ćwiczenia zaproponować grupie rozmowę na temat relacji pomiędzy przekonaniami i emocjami.

Model coachingowy uprawiania filozofii jest dziś szansą dla tej dyscypliny, która jak każda dziedzina wiedzy ludzkiej powinna znajdować swoje bardzo konkretne praktyczne zastosowania. Włączanie ćwiczeń duchowych do programu filozofii sprawia, że przestaje być ona zbiorem oderwanych od życia abstrakcji - staje się narzędziem samopoznania i rozwoju. Może stanowić też wyzwanie dla psychoterapuetów, którzy leczą ludzką psychikę, pomijając jej wymiar duchowy, związany np. z wartościami religijnymi i ujmowaniem życia jako sensownej całości. 


\section{BIBLIOGRAFIA}

Arystoteles, Etyka Nikomachejska, tłum. z gr. D. Gromska, Kraków 1956.

Calouri D., Plotinus on the Soul, Cambridge 2015.

Frankl V., Bóg ukryty. W poszukiwaniu ostatecznego sensu, tlum. z niem. A. Wolnicka, Warszawa 2016.

Frankl V., Cztowiek w poszukiwaniu sensu, tłum. z niem. A. Wolnicka, Warszawa 2013.

Frankl V., The Unheard Cry for Meaning, New York 1979.

Gallwey T., Tenis. Wewnętrzna gra, tłum. z ang. R. Madejczyk, Łódź 2015.

Hadot P., Czym jest filozofia starożytna?, tłum. z fr. P. Domański, Warszawa 2000.

Hadot P., Filozofia jako ćwiczenie duchowe, tłum. z fr. P. Domański, Warszawa 2003.

Hadot P., Twierdza wewnętrzna. Wprowadzenie do „Rozmyślañ” Marka Aureliusza, tłum. z fr. P. Domański, Warszawa 2004.

Jones E., The life and work of Sigmund Freud, New York 1953-57.

Längle A., Analiza egzystencjalna - poszukiwanie zgody na życie, Psychoterapia (2003)2, 33-46.

Längle A., Gdy rodzi się pytanie o sens. Praktyczne zastosowanie logoterapii, thum. z niem. A. Grzegorczyk, Warszawa 2016.

Lotz J.B., Wprowadzenie w medytację, tłum. z niem. J. Zychowicz, Kraków 1983.

Platon, Fajdros, tłum. z gr. W. Witwicki, Kęty 2002.

Platon, Gorgiasz. Menon, tłum. z gr. P. Siwek, Warszawa 1991.

Platon, Timajos, tłum. z gr. P. Siwek, Warszawa 1986.

Popielski K., Koncepcja logoteorii V. E. Frankla i jej znaczenie w poradnictwie psychologiczno-pastoralnym, w: Wybrane zagadnienia z psychologii pastoralnej, red. Z. Chlewiński, Lublin 1989, 69-101.

Powszechna encyklopedia flozofii, t. 8, red. A. Maryniarczyk, Lublin 2007.

Rohr R., Ebert A., Enneagram: dziewięć typów osobowości, tlum. z ang. A. Kleszcz, Kraków 2004.

Russo L., Zapomniana rewolucja: grecka myśl naukowa a nauka nowoczesna, tłum. z wł. I. Kania, Kraków 2005.

Stoś J., Krytyka metody scholastycznej oraz schola mystica w pismach Jakuba z Paradyża, Studia Philosophiae Christiane 36(2000)2, 243-266.

Weil S., Szaleństwo mitości. Intuicje przedchrześcijańskie, tłum. z fr. M. Plecińska, Poznań 1994.

Whitehead A.N., Nauka i świat wspótczesny, tłum. z ang. S. Magala, Warszawa 1988. 
Whitehead A.N., Rythm of education, London 1922.

Whitehead A.N., The Aims of Education and Other Essays, New York 1967/29.

\title{
PHILOSOPHY AS A SPIRITUAL EXERCISE. THE COACHING PARADIGM OF PHILOSOPHY
}

Abstract. The claim that philosophy should be cultivated in a coaching style is the main thesis of this article. In the first part of the essay, I explain the distinction between a coaching (Socratic) paradigm and a scholastic (Aristotelian) paradigm of philosophy . In the second part , I present Frankl's logotherapy as an example of Socratic or coaching philosophy. The coaching model of philosophy, neglected by mainstream philosophy, found its place in humanistic psychotherapy. Finally, the last section of the article contains some practical examples of coaching methods applied to the teaching of philosophy (epistemology).

Keywords: coaching model, scholastic model, logotherapy, consciousness, spiritual exercise, coaching exercise

\author{
PIOTR LEŚNIAK \\ piotrlesniak@uni.opole.pl \\ Uniwersytet Opolski, Wydział Nauk Społecznych, Instytut Filozofii \\ Katowicka 89, 45-061 Opole
}

DOI: 10.21697/spch.2018.54.3.11 